\title{
In Memoriam: William E. Westerbeke
}

\author{
Michael J. Davis*
}

In the spring of 1974, University of Kansas School of Law Professors Malcolm and Louise Wheeler announced that they would be leaving the faculty at the end of the semester to return to Los Angeles, where they practiced law before joining KU Law in the fall of 1971. For each of his three academic years on the KU Law faculty, Mal taught antitrust law, a hot topic at the time. He also committed to teach the course during the upcoming 1974 summer school term and the course schedule had been printed and relied on by students for several months. To help the law school fill the gap his departure would create, Mal recommended it hire a young lawyer he befriended while they were both serving on the Stanford Law Review. Following this recommendation, Associate Dean Barkley Clark phoned William E. Westerbeke, an associate at the prestigious Los Angeles law firm of O'Melveny \& Myers, and offered him a five-week visiting summer position to teach antitrust law. Westerbeke had never practiced antitrust law but was, at the time, a litigation associate working on an important antitrust case. That was enough substance for Dean Clark, and thus Westerbeke came to KU Law as a five-week summer fill-in for his departing friend. The five weeks went well for both the law school and the substitute, and the following academic year Westerbeke was offered a full-time Associate Professor position beginning in the fall of 1975. He accepted, returned to Lawrence the next summer, and in late August 1975 began a career that would span over forty years in a town he would never leave. ${ }^{1}$ He would eventually retire in the spring of 2017 as one of the law school's most productive, respected, and beloved faculty members of his era.

Few, if any, would have predicted that Beke, as he became widely known, would live most of his adult life as a Kansan. He grew up in Quincy, Massachusetts, just outside Boston. He graduated from Bowdoin College in Brunswick, Maine, where he played goalie for the

\footnotetext{
* Centennial Teaching Professor Emeritus of Law, University of Kansas School of Law.

1. See KU Law Community Mourns Passing of Retired Professors George Coggins and William Westerbeke, UNIV. OF KAN SCH. OF LAW (Sept. 4, 2019), https://law.ku.edu/ku-law -community-mourns-passing-retired-professors-george-coggins-and-william-westerbeke [https:// perma.cc/EQW7-5C6Z].
} 
lacrosse team and filled in as a German instructor. Two years as an Artillery officer in the United States Army followed, including a station at the American base at Baumholder, West Germany, where he continued to improve his German. The following year, he earned an M.A. from Middlebury College in Vermont, perfecting his second tongue. From there, it was off to the West Coast for law school, a prestigious clerkship with United States District Judge Irving Hill of the Central District of California, and the O'Melveny associate position. He had no hint of interest in the Midwest - a short, mandatory Army stay at Fort Sill, Oklahoma notwithstanding.

But the mutual attraction that drew KU Law to Beke and vice versa grew into a lifetime love affair. Much of the attraction stemmed from his voracious and enduring appetite for teaching. His $\mathrm{KU}$ Law $\mathrm{CV}$ lists thirteen different courses taught at some point during his forty-two years. His principal focus was always Torts and tort-related courses such as Product Liability and Worker's Compensation. He taught Torts I every year, usually twice (summer and fall). It was in that first-year atmosphere where energy abounded and no one had yet been graded that he found the most satisfaction. As hundreds of his former student attest, his recognized effectiveness flowed from a deft combination of Socratic skill and an always overflowing desire that everyone understand the basics. While there were always notes on the podium, he seldom referenced them. During a full blackout at the law school one afternoon, he famously just kept lecturing. Exactly what the students were supposed to do during the time was never clear. Because of his prolific writing, within a single decade Beke had become the acknowledged torts authority of the state of Kansas and Midwest region.

But torts was by no means Beke's only teaching specialty. His Judicial Clerkship Clinic (1988-1995) was the first of its kind at the law school and placed students in clerkships with trial and appellate courts throughout the state. His reinstitution and supervision of the National Moot Court Competition and team (1975-1988) included a new appellate practice course and an in-house moot court competition. His team's renewed participation in the National Moot Court Competition resulted in $\mathrm{KU}$ Law advancing through the regional competition to the national tournament six of the next twelve years, including a second-place national finish in 1988, and a national championship (Justice O'Connor presiding) in 1984.

Beke and his colleague, David Gottlieb, also began a seminar on the First Amendment religion clauses, a course they persuaded me to join as a third wheel. Because of my schedule as Dean, the class met Saturdays from 9 AM to 3 PM each spring semester in Beke's house on 19th 
Terrace. It was a freewheeling, open discussion among three senior faculty members and ten to twelve students regarding the many knotty problems raised by the first sixteen words of the Bill of Rights, issues constantly fueled by frequent and often opaque decisions by the United States Supreme Court. The student evaluations of the course were resoundingly positive, often including phrases such as "favorite course" and "this is what I hoped law school would be like."

Despite always maintaining one of the heaviest teaching loads in Green Hall, Beke never confined his teaching to law students. He enjoyed teaching "Introduction to the American Legal System" to undergraduate students, which he did at both Haskell Indian Nations University and, for five summers, KU undergrads at Cambridge University in the United Kingdom. In 2006, he was Program Director and principal teacher of KU Law's summer program in Ireland, and in 1990, spent the spring semester at the law school's exchange program at the University of Vienna, where, unlike the rest of us, he taught auf Deutsch. Beke's international interests were also reflected in several lectures he gave on aspects of U.S. tort law to law faculty, law students, judges, and practicing lawyers across Europe: University of Aberdeen, Scotland, United Kingdom (2003); University of Limerick, Ireland (2002); University of Marmara, Istanbul, Turkey (1999); Cambridge, United Kingdom (1997); and Krems, Austria (1990) — that one again auf Deutsch.

Unsurprisingly, Beke was often honored for his teaching. Among the most prominent recognitions were the Fredrick J. Moreau Award for Student Advising and Counseling, the Immel Annual Teaching Award, the Dean James Green Fellowship Award, and the Robert A. Schroeder Teaching Fellowship. Most strikingly, in 2006 he was given the Kemper Award for Teaching Excellence, an honor covering the entire KU Lawrence campus.

While teaching was Professor Westerbeke's first love, it was by no means his only contribution to KU, his law school, and his state. While-not uncharacteristically_his last "updated" CV leaves off in 2011 (six years before his retirement), his "Publications" list is thirty-four entries long. As the list includes at least one publication for every year between 1989 and 2011, one could safely assume it would have exceeded forty if truly "updated."

Much of this scholarship concerned Kansas tort law. His annual torts contributions to the Kansas Bar Association Annual Survey of Kansas Law, a review of both legislative and judicial developments in the field, encompassed over half of his publications. For torts scholars, whose primary mission was to alter the paradigm of compensation for 
civil wrongs, this was undoubtedly prosaic stuff. But for hundreds of working attorneys and judges from Kansas and elsewhere, these texts were an annual booster shot on one of the most basic areas of civil legal practice. It is from these surveys that Professor Westerbeke's reputation as "Mr. Torts" primarily sprang. The contents of the surveys were frequently the groundwork for briefs in both trial and appellate cases, and often prompted phone calls from former students and total unknowns alike seeking further insights on particular subtopics. Beke took these calls as he could whenever they came, helped to the extent he was ethically able, and never charged a penny.

He often supplemented his writings with personal appearances in continuing legal education programs across the state. The-again abbreviated $\mathrm{CV}$ - enumerates at least two dozen such lectures over thirty years from Overland Park to Dodge City, Wichita to Colby. It would have been difficult not to become "Mr. Torts" under those circumstances.

Yet it would be shortchanging Beke's scholastic record to cite only these annual reviews. While almost all of his writings and presentations covered the torts field generally, several targeted specific topics or called for reform. In Praise of Arbitrariness: The Proposed 83.7\% Rule of Modified Comparative Fault, ${ }^{2}$ The Immunity Provisions in the Kansas Tort Claims Act: The First Twenty-Five Years, ${ }^{3}$ and Strict Products Liability for Misrepresentation ${ }^{4}$ reflect an intent to guide the law to better places rather than just reflect its current state.

Steve McAllister, current United States Attorney for Kansas, was Beke's colleague for over twenty years, his Dean for five of those years, and also a renowned torts teacher and scholar. At my request, he summed up the impact of Beke's scholarship: "He had . . . an uncanny ability to predict where Kansas tort law was likely to go before it did, sometimes to his chagrin, because he did have some strong opinions about fairness and practicality, as well as what Kansas lawmakers ought to do." $\mathrm{He}$ added a more personal perspective on Beke's methodology, which also gave insight on Beke's character: "I thoroughly enjoyed Beke's encyclopedic knowledge of Kansas tort law, his candor, his

2. William E. Westerbeke, In Praise of Arbitrariness: The Proposed 83.7\% Rule of Modified Comparative Fault, 59 U. KAN. L. REV. 991 (2011).

3. William E. Westerbeke, The Immunity Provisions in the Kansas Tort Claims Act: The First Twenty-Five Years, 52 U. KAN. L. REV. 939 (2004).

4. William E. Westerbeke, Strict Products Liability for Misrepresentation, J. KAN. TRIAL LAW. ASs'N, Nov. 1997, at 20.

5. Email from Stephen R. McAllister, U.S. Att'y for the Dist. of Kan., to Michael J. Davis (Dec. 18, 2019, 11:11 PM CST) (on file with author). 
nonpartisan objectivity, and his irrepressible sense of humor about all of it. There was nothing abstract about Beke's approach to his scholarship . ... He wrote to make a difference in Kansas, and he did."6

As a final aspect of his faculty responsibilities, Beke was also a great servant of the law school, the university, and the state. He testified numerous times to state legislative committees and served several years on the Civil Code Advisory Committee of the Kansas Judicial Conference. He held a number of nonremunerative positions on the Lawrence campus, including three years on the University Senate Executive Committee (1976-1979), the last year of which he was chair. He also chaired the University Tenure Relations Board (2006-2009). In his last decade on the faculty, he was a relentless volunteer tutor for both the KU Football team and the KU Volleyball team, for which he was also an ardent season ticket holder. His service at the law school was deep and broad. He served on the Admissions Committee, a Dean Search Committee, the Placement Committee, and the Faculty Recruitment Committee. He was particularly adept at two unnamed skills: 1) advising students regarding both academics and life; and 2) preparing dossiers for law school recommendations supporting faculty requests for tenure and promotions to the appropriate University Committee. He was among the best in the building at student advising, and was absolutely the best at dossier-prep - the law school never once had a promotion or tenure request denied.

This piece so far has chronicled why Bill Westerbeke was regarded as one of the finest faculty members in Green Hall for four decades. Great teacher, important scholar, tireless worker, willing and able servant to all. What is as yet unwritten is why he was beloved as well as respected, more impactful as a human being than admired faculty member. There are some hints within the McAllister quote above: "candor," "nonpartisan objectivity," "irrepressible sense of humor."7 But Steve was only addressing a narrow topic. A full account of why Beke was such an endearing figure requires a brief look at his personality, his character, and his passions.

He was inarguably an unforgettable personality. Large in stature, he was full of humor, coffee, opinions, insights, memories, and commentary. Lots of commentary. Just ask a question and sit back (though the question was often unnecessary). Approachable and gregarious by nature, he truly never met a stranger, a viewpoint seldom 
affected by the status, gender, race, income, or dress of his new or old friend. If there were any tenancies there, they were inverted-the homeless guy on the street was more interesting and worthy of Beke's time than the state senator from XYZ. While he often kept his own counsel in rambunctious faculty (and other) meetings, in person or small groups, you never had to speculate about what was on Beke's mind.

Beyond personality, of course, comes character. Many words can describe Beke's inner self. Honest, candid, loyal, good natured, fair minded and understanding come immediately to mind. But the most fitting single word is probably "generous." Above all, Beke was generous. Generous in time, generous in treasure, and, most important, generous in spirit. It was widely known that Beke lived below his means and, later in life, came into some inherited wealth. Few, however, know how often and widely Beke contributed his resources to groups and individuals he found worthy of his support. Some, like the Lawrence Humane Society and the KU Law School were generally known. Many other donees, however, were not, including the many individuals who benefitted directly from his (nondeductible) charity. He was equally generous with his time. His gift of gab notwithstanding, he invariably made time for anyone. He was a compassionate person who never missed an opportunity to offer a cheerful word or note of consolation to those whom he felt were in need. Motivating all of these acts of kindnesses was his overwhelmingly generous spirit. He recognized the privilege of who he was, how he was raised and educated, the good fortune of his chosen profession, and his abiding confidence in his family and friends. From that internal peace sprang a palpable sense of responsibility to help others find their own potential, confidence, success, and peace. He was a good man.

Beke's passions were the final ingredients essential to a full understanding of why Beke remains dear to so many. Like many of us, what he chose to embrace most tightly constituted peepholes into his soul, his principal motivations for rising at $5 \mathrm{AM}$ - as he usually didand having a wonderful day without regard to health, weather, the political landscape, or the workload ahead.

Certainly, his love for the law, the truth, and his students was high on that list. He loved his job and, not surprisingly, it loved him back. But for the last forty years of his life, his first charges every morning were not his students but his dogs. The first two were certified labs (Cody and Sadie), but after them came a succession of adoptees from the animal shelter with nicknames such as "Psycho" and "Chicken Killer." He soon became a permanent fixture at the Lawrence dog park, where he made many new friends and, undoubtedly, told many new stories. An 
important offshoot of this passion was his decade-long service on the Lawrence Humane Society board, where his influence was so large that it sponsored a memorial service for him at his passing.

Another enduring passion was for the game of golf, a pursuit he undertook in his West Coast years and carried with him to Lawrence, where it soon grew into a major aspect of his being. A few years after his arrival he joined the Alvamar Country Club, now uniquely licensed as The Jayhawk Club, where he spent over thirty years working to "improve" his game. Improvement often proved a struggle despite, or perhaps because of, his faithful playing five to seven days a week for the eight or nine Eastern Kansan months the course was available. Many new clubs and hundreds of golf balls lived and died in pursuit of a moveable goal of shooting "under 100" on a consistent basis, which eventually happened. Indeed, after at least twenty years of battling this bête noir, he almost overnight began shooting in the eighties with some regularity. Those last glorious years were among the happiest in Beke's lifetime, ending only when his body refused to go on with the sport. Golf was also a favorite watching activity. He and I attended three Open Championships in the UK, and he made several tours both there and in Ireland. He died with a superb golf memorabilia collection of balls and markers from major courses and tournaments here and abroad. Even law students benefitted from this passion. The pro at Alvamar was a good friend of ours, and at his suggestion, one spring semester we offered an inexpensive set of group lessons one afternoon a week for law students only. It was a great hit, and for the next fifteen to twenty years-with Beke solely in charge - twelve to twenty students each spring enjoyed an initial dipping into the difficult sport of hitting the little white ball far and straight.

Three other passions bear mention. Anyone within earshot knew that Beke fervently supported political causes that advanced his vision of a fairer economy and a more inclusive society. MSNBC was his network of choice. He cared deeply and supported widely, and the political topic of the day was his usual conversation starter with his friends.

Sports and music were also major time investments. Beke was a fine athlete in his own right: the lacrosse goaltender for his undergraduate school and an active participant in basketball, touch football, and fastpitch softball during his faculty years. He was also a fervent fan, often attending both Kansas City professional games and especially $\mathrm{KU}$ basketball and volleyball contests. He also rooted-semi-secretly-for Notre Dame in football, occasionally describing himself as "President of Huguenots for Notre Dame."

His musical tastes ran from opera (he had a lovely tenor voice) to 
Celtic ballads to the great music of his twenties and thirties-Dylan, the Stones, Paul Simon, the Beatles, and James Taylor, among others. He always had first class sound equipment and used it often while relaxing after a day on the course or at the dog park. He left a treasure trove of CDs and vinyl recordings to be shared by those of the same musical taste.

To close with a particularly sentimental remembrance, Beke did have one other nickname, one of which he was very proud. He was Uncle Bill to many faculty and other children for whom he became a dinner companion, a relentless gift giver, a godfather, a baseball manager, a faithful attender-of-events, or, as in my children's case, all-of-the-above. Only as an example, my daughter is now forty-three. Beke attended her baptism/first communion/confirmation; every graduation from junior high school through college in Nashville; every birthday party; and now that she is a professional musician, every local concert she gives. He was Surprise Santa for her, her brother, and other faculty kids during their early years. And he would often take my children and others out to dinner for "carrots and spinach," a trip that invariably ended at Pizza Hut. All of this how and why a Uncle Bill, a lifelong bachelor, leaves behind not only several thousand grateful former students, but also dozens of other adults now in their thirties and forties who worshiped him as a child, became his good friends as adults, and mourn him with the rest of us at his passing. Just one more of the many lessons to take away from a life well led.

See you Beke, and thanks for the memories. Since you left, every time I mention your name the other person smiles. Which tells me that something important is missing for more of us than you could have imagined. 